\title{
THE RELATIONSHIP BETWEEN FREQUENCY OF LISTENING AND VOCABULARY MASTERY TOWARD LISTENING ABILITY AT THE FIRST GRADE STUDENTS OF MAN 4 KEDIRI
}

\author{
Aprilia Ayuning Tias, Kristanti Yuntoro Putri
}

\begin{abstract}
In this research, the researcher examined the correlation between frequency of listening and vocabulary mastery toward listening ability at first grade students of MAN 4 Kediri. The aim of the research was to find out (1) the students' frequency of listening, (2) the students' vocabulary mastery, (3) the students' listening, (4) the significant simultaneous relationship between frequency of listening and vocabulary mastery toward listening ability, and (5) the significant partial relationship between frequency of listening and vocabulary mastery toward listening ability at the first grade students at MAN 4 Kediri. This research can be categorized as Quantitative correlation. The technique to collect data was the questionnaire and test. The questionnaire used to collect the data of frequency of listening and the test was for collecting the data of vocabulary mastery and listening ability. The instrument contained of 20 questions for each variable. In this case, the first grade students of science classes, totally 136 students, were taken as population and 100 students as sample by Sloven formula. The result of students' frequency of listening is that $75 \%$ or 75 students are in good category. For the students' vocabulary mastery, there are $43 \%$ or 43 students who are in very good category. The students' listening ability is $30 \%$ or that 30 students are in good category. To find out the correlation between three variables in this research used the SPSS 15,0 version. The result of significant level is 0,731 (a). It is more than $5 \%$ significant level. It means that there is no significant correlation between frequency of listening and vocabulary mastery toward listening ability at the first grade students of MAN 4 Kediri. So, the alternative hypothesis was rejected.
\end{abstract}

Keyword: frequency of listening, listening ability, vocabulary

\section{INTRODUCTION}

Listening is the way to understand what people say and that is the learners are trying to learn in English. According to the definition of listening given by Brown and Yule (1983), "listening is the activity of paying attention to and trying to get the meaning from something we hear". Something what somebody hears means like conversation, story, explanation and so on, which may give the listeners the new information.

Nahdliyatinniswah (2016) writes that many students consider that listening is difficult. The students do not understand what they listen in English; it means that their listening skill is still low. The factors that influence it are: (1) The 
material is so fast to be listened, (2) The students have limited vocabulary, (3) The students are less focus, (4) The students do not know what the instruction is and they are lazy in studying. So, they just ignore and do not study the listening lesson. If they have good listening skill, it can help them to understand easily what native or other people say in English. Teachers generally believe that the listening skill emerges spontaneously in time, just like breathing. However, listening skill can only be improved by hard work and repetition as it is the case in reading skill (Kutlu \& Aslanolu, 2009).

Teacher will measure the students' listening ability by one of the ways which is from their vocabulary mastery. Pikulski and Templeton (2004) stated that there is no question that people who have large speaking vocabularies generally tend to have large listening, reading, and writing vocabularies, like wise people who are limited in one of these aspects are likely limited in other aspects as well. It can be said that vocabulary is one of the elements in language. Among all the elements of language have interaction with others elements. Ur (1996: 60) cited in Setyo (2017) defined, "vocabulary as the words we teach in the foreign language". Interpreting from Ur, vocabulary is a number of English words which is taught to students in teaching learning process to support listening ability. Vocabulary is very important because without vocabulary, sentences cannot be understood by the people.

Ramdlany (2010) says that vocabulary has the important role in communication, more over orally. It is trusted that the more students master the vocabulary, the easier they can improve their four skills in English. It means that the vocabulary cannot be considered in an importance, because it has the big role in English skill, especially in listening.

Another factor that supports listening skill of students is frequency of listening. Good (1979:274) cited in Setyo (2017) says that frequency is an act or movement of behavior that through practice has become easy and familiar, and it is performed without conscious thought or hesitancy. Frequency is a repetitive action or repetition activity that brings an inclination to do it automatically, regularly and unconsciously. Afterwards, finally become a pattern of behavior as a result of repetition activity. In addition, frequency deal with doing activity related to hobby, talent, favorite activity or personal choice continuously, though it is done unconsciously. Another definition of listening is given by Brown and Yule (1983). They say that listening is the activity of paying attention to and trying to get the meaning from something we hear. From the definition above, it can be concluded that listening is an active process of paying attention to and trying to get the meaning from something the people hear which is at present unknown.

The students' frequency in studying takes an essential part in the students' achievement. In the daily life, there are many parents get trouble with their children in studying. The children will be forced to study regularly. To face this reality, it is needed some ways to solve or to push the frequency up minimally, because the frequency in studying will never grow up naturally (include the students' heredity), by this frequency will grow up the intensive program. So by their frequency listening in English and vocabulary mastery, it can be the 
alternative ways of learners to improve their listening ability if the learners do more and more experience in listening. Here the researcher has known if many factors can influence the students' achievement, and frequency of listening monolog also as one of factors to give good effect in English learning process.

Based on the description above, the conclusion is that vocabulary mastery and the frequency of listening can be essential factors for listening ability. Vocabulary is the indicator of assessment listening test, it means that if students need their listening improved they have to master a lot of vocabulary, and the frequency of listening can give more experience to the students in listening test.

The study intends to answer the following questions; 1) How is the students' frequency of listening at MAN 4 Kediri; 2) How is the students' vocabulary mastery at MAN 4 Kediri; 3) How is the students' listening ability at MAN 4 Kediri; 4) How is the significant simultaneous relationship between frequency of listening and vocabulary mastery toward listening ability at the first grade students at MAN 4 Kediri; 5) How is the significant partial relationship between frequency of listening and listening ability controlled by vocabulary mastery at the first grade students at MAN 4 Kediri; 6) How is the significant partial relationship between vocabulary mastery and listening ability controlled by frequency of listening at the first grade students at MAN 4 Kediri.

\section{RESEARCH METHOD}

The research method used correlation method. Hallonen and Santrock (1999: 20) state that correlation method whose goal is to describe the relation between two or more events or characteristics. The reason of choosing this method was the researcher wanted to know the strength of the relation of two or more variables based on correlation coefficient. There are three variables in this study; two independent variables (X) and one dependent variable (Y). Those are; frequency of listening (X1), vocabulary mastery (X2), and listening ability (Y)

The subject was the science classes of first grade students. In determining the subject of research, it was taken by using sample theory of Sloven. The sampling was random sampling technique that the subject or class chosen was $\mathrm{X}$ MIA - 1, X MIA - 2, X MIA - 3, X MIA - 4. The sample student of each class was 25 students.

The research instruments in this research were questionnaire and test. The questionnaire was used to obtain the data of frequency of listening. The indicators of frequency of listening were repetitive action, paying attention and getting the meaning. In this study, there were 20 items and 4 option answers. The way to score based on Husaini and Purnomo (1996: 69) is as follows: (1) Positive statement: Selalu (SL) is scored 4, Kadang-kadang (KD) is scored 3, Jarang (JR) is scored 2, Tidak Pernah (TP) is scored 1. (2) Negative statement: Sangat setuju (SS) is scored 1, Setuju (S) is scored 2, Kurang setuju (KS) is scored 3, Tidak setuju (TS) is scored 4.

The test was used to get the data of vocabulary mastery and listening ability. The students' vocabulary mastery will be scored based on identifying the language feature, which was limited on finding the meaning of words, synonyms, antonyms, and hyponym on monologue of English recount text about past 
experience. The students' listening ability will be scored based on identifying the detail information on monologue of English recount text about past experience. The researcher marked 1 for each item if the students answered correctly, and the researcher marked 0 if the students answered incorrectly.

The purpose of this study was to find out the relationship between frequency of listening and vocabulary mastery toward listening ability at first grade students of MAN 4 Kediri. So, to get the relationship between frequency of listening and vocabulary mastery toward listening ability at the first grade students of MAN 4 Kediri, the researcher had to count the scores to analyze the data. After collecting data from questionnaire and test, the data was analyzed to find out the mean, median and standard deviation of variable $\mathrm{X} 1, \mathrm{X} 2$, and $\mathrm{Y}$. To find out the influence among three variables, regression was used as the formula to compute the all of data.

\section{RESEARCH FINDING}

\section{The Frequency of Listening $\left(\mathrm{X}_{1}\right)$}

This research used 136 students as population and took 100 students as sample. Questionnaire was used to collect the data of $X_{1}$ variable. There were 20 multiple choice questions. The score frequency of variable $X_{1}$ or frequency of listening was served in SPSS standard table. The researcher found the frequency by using SPSS 15.0 version software.

Table 4.1 Descriptive Statistic of variable $X_{1}$ (Frequency of Listening)

Statistics

\begin{tabular}{|ll|r|}
\hline $\mathrm{N} 1$ & Valid & 100 \\
& Missing & 0 \\
Mean & & 68,55 \\
Std. Error of Mean & & 935 \\
Median & & 71,00 \\
Mode & & 71 \\
Std. Deviation & & 9,354 \\
Variance & & 87,503 \\
Range & & 39 \\
Minimum & & 49 \\
Maximum & & 88 \\
Sum & 25 & 6855 \\
Percentiles & 50 & 64,00 \\
& 75 & 71,00 \\
& & 74,00 \\
\hline
\end{tabular}


The mean is 68,55 . Median is 71,00 . Mode is 71 and $\mathrm{SD}_{\mathrm{x} 1}$ is 9,354 . The last data shown is percentiles. There are 3 percentiles found there. They are percentile 25,50 , and 75 . The values are $64.00,71.00,74.00$. There is the classification of Frequency of Listening $\left(\mathrm{X}_{1}\right)$. From this table it can be seen the categorization of each score in each variable and how many numbers of score that belong to each categorization is.

Table 4.2 Categorization of Variable $\mathrm{X}_{1}$ (Frequency of Listening)

\begin{tabular}{ccccc}
\hline NO & INTERVAL & FREQUENCY & PRECENTAGE & QUALIFICATION \\
\hline 1 & $81-100$ & 4 & $4 \%$ & VERY GOOD \\
2 & $61-80$ & 75 & $75 \%$ & GOOD \\
3 & $41-60$ & 21 & $21 \%$ & FAIR \\
4 & $21-40$ & 0 & $0 \%$ & BAD \\
5 & $0-20$ & 0 & $0 \%$ & VERY BAD \\
\hline & TOTAL & 100 & $100 \%$ & \\
\hline
\end{tabular}

From the table it can be seen that $4 \%$ or 4 students got very good value, $75 \%$ or 75 got good value, $21 \%$ or 21 got fair value and there is no students got bad score in frequency of listening. From the explanation above, it can be concluded that the students' frequency of listening belonged to "good" category.

\section{The Vocabulary Mastery $\left(\mathbf{X}_{2}\right)$}

This research used 136 students as population and took 100 students as sample. Test was used to collect the data of $\mathrm{X}_{2}$ variable. There were 20 multiple choice questions. To find out the result of variable $\mathrm{X}_{2}$ or vocabulary mastery was from score frequency. The score frequency of variable $\mathrm{X}_{2}$ or vocabulary mastery is served in SPSS standard table.

Table 4.3 Descriptive Statistic of variable $\mathrm{X}_{2}$ (vocabulary mastery)

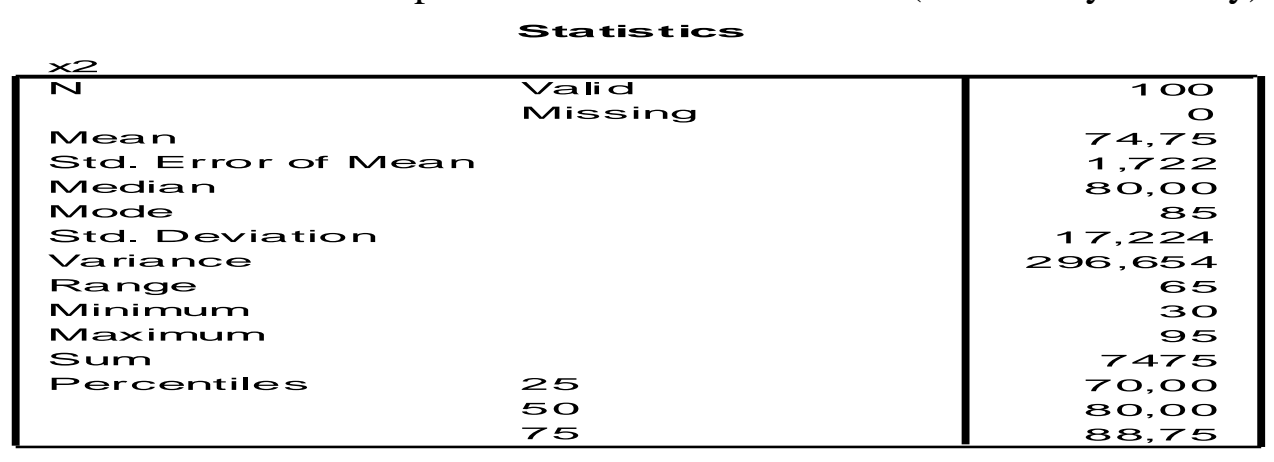

The mean is 74,75 . Median is 80,00 . Mode is 85 , and $\mathrm{SD}_{\mathrm{x} 1}$ is 17,224 . The last data shown is percentiles. There are 3 percentiles found there. They are percentile 25, 50, and 75. The values are 70.00, 80.00, and 88.75. There is the classification of Vocabulary Mastery $\left(\mathrm{X}_{2}\right)$. From table 4.3 , it can be seen the 
categorization of each score in each variable and how many numbers of score that belong to each categorization is.

Table 4.4 Categorization of Variable $\mathrm{X}_{2}$ (Vocabulary Mastery)

\begin{tabular}{ccccc}
\hline NO & INTERVAL & FREQUENCY & PRECENTAGE & QUALIFICATION \\
\hline 1 & $81-100$ & 43 & $43 \%$ & VERY GOOD \\
2 & $61-80$ & 37 & $37 \%$ & GOOD \\
3 & $41-60$ & 11 & $11 \%$ & FAIR \\
4 & $21-40$ & 9 & $9 \%$ & BAD \\
5 & $0-20$ & 0 & $0 \%$ & VERY BAD \\
\hline & TOTAL & 100 & $100 \%$ & \\
\hline
\end{tabular}

From the table it can be seen that is $43 \%$ or 43 students got very good value, $37 \%$ or 37 students got good value, $11 \%$ or 11 students got fair value, $9 \%$ or 9 students got bad value of vocabulary mastery and there is no students got very bad value of vocabulary mastery. From the explanation above, it can be concluded that the students' vocabulary mastery belonged to "very good" category.

\section{The Listening Ability (Y)}

This research used 136 students as population and took 100 students as sample. Test was used to collect the data of $\mathrm{Y}$ variable. To know the result of variable $\mathrm{Y}$ or Listening Ability was from score frequency. The score frequency of variable Y or Listening Ability is served in SPSS standard table.

Table 4.5 Descriptive Statistic of variable Y (Listening Ability)

Statistics

\begin{tabular}{|ll|r|}
\hline $\mathrm{y}$ & $\begin{array}{c}\text { Valid } \\
\text { Missing }\end{array}$ & 100 \\
Mean & & 0 \\
Std. Error of Mean & & 54,10 \\
Median & & 2,304 \\
Mode & & 55,00 \\
Std. Deviation & & 30 \\
Variance & & 23,043 \\
Range & & 531,000 \\
Minimum & 80 \\
Maximum & & 15 \\
Sum & & 95 \\
Percentiles & 25 & 5410 \\
& 50 & 30,00 \\
& 75 & 55,00 \\
\hline
\end{tabular}

The mean is 54,10 . Median is 55,00 . Mode is 30 and $\mathrm{SD}_{\mathrm{y}}$ is 23,043 . The last data shown is percentiles. There are 3 percentiles found there. They are 
percentile 25, 50, and 75. The values are 30.00, 55.00, and 75.00. There is the classification of Listening ability like frequency of listening and vocabulary mastery. From table 4.5 it can be seen the categorization of each score in variable Listening ability and how many numbers of score that belong to each categorization are.

Table 4.6 Categorization of Variable Y (Listening Ability)

\begin{tabular}{ccccc}
\hline NO & INTERVAL & FREQUENCY & PRECENTAGE & QUALIFICATION \\
\hline 1 & $81-100$ & 12 & $12 \%$ & VERY GOOD \\
2 & $61-80$ & 30 & $30 \%$ & GOOD \\
3 & $41-60$ & 23 & $23 \%$ & FAIR \\
4 & $21-40$ & 26 & $26 \%$ & BAD \\
5 & $0-20$ & 9 & $9 \%$ & VERY BAD \\
\hline & TOTAL & 100 & $100 \%$ & \\
\hline
\end{tabular}

From the table it can be seen that is $12 \%$ or 12 students got very good value, $30 \%$ or 30 students got good value, $23 \%$ or 23 students got fair value, $26 \%$ or 26 students got bad value, and $9 \%$ or 9 students got very bad value in listening ability. From the explanation above, it can be concluded that the students' listening ability on the data analysis variable Y belonged to "good" category.

\section{The result of Simultaneous Relationship between Frequency of Listening and Vocabulary Mastery toward Listening Ability.}

This research purposed to find out the relationship between frequency of listening and vocabulary mastery toward listening ability at the first grade students of MAN 4 Kediri. The alternative hypothesis which stated that there is significant relationship between frequency of listening and vocabulary mastery toward listening ability at the first grade students of MAN 4 Kediri can be rejected by the descriptive analysis of all variables and the regression correlation computation. The next, the correlation value is served at SPSS table. The table shows the variables used in regression. They are Students' Frequency of Listening $\left(\mathrm{X}_{1}\right)$, Vocabulary Mastery $\left(\mathrm{X}_{2}\right)$ and Students' Listening Ability $(\mathrm{Y})$.

Table 4.7 Coeficient Correlation

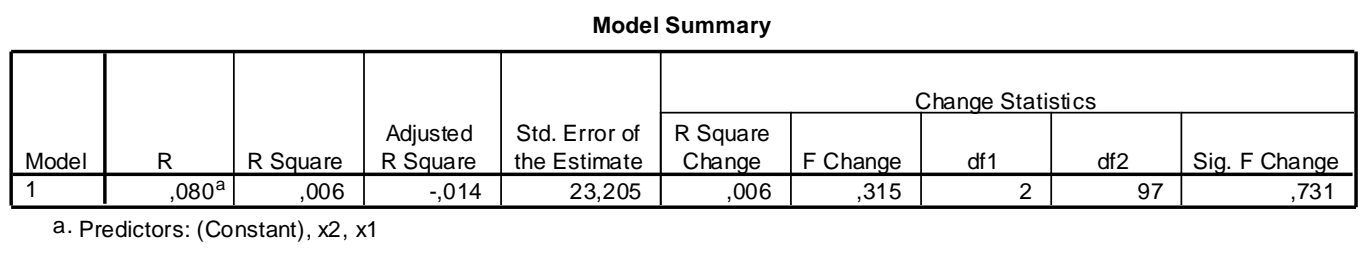

a Predictors: (Constant), vocabulary mastery, frequency of listening

Based on table 4.1, the value of $\mathrm{R}$ is 0,080 (a), $\mathrm{R}$ Square is 0,006 , Adjusted $\mathrm{R}$ Square is $-0,014$, the Standard Error of the Estimate is 23,205, Sig. F Change is 0,731 and $\mathrm{R}$ Square Change is 0,006 . 
Table 4.8 The Significance of Regression

ANOVA

\begin{tabular}{|ll|r|r|r|r|r|}
\hline Model & & $\begin{array}{c}\text { Sum of } \\
\text { Squares }\end{array}$ & df & Mean Square & F & Sig. \\
\hline 1 & Regression & 338,996 & 2 & 169,498 &, 315 &, $731^{\mathrm{a}}$ \\
& Residual & 52230,004 & 97 & 538,454 & & \\
& Total & 52569,000 & 99 & & & \\
\hline
\end{tabular}

a. Predictors: (Constant), $x 2, x 1$

b. Dependent Variable: $y$

The relationship used here simultaneous correlation (Regression) which value is 338,996 . The significant level is 0,731 (a). It is more than 5\% significant level. It means the alternative hypothesis is rejected. There is no significant simultaneous relationship between frequency of listening $\left(\mathrm{X}_{1}\right)$ and vocabulary mastery $\left(\mathrm{X}_{2}\right)$ toward listening ability $(\mathrm{Y})$ at the first grade students of MAN 4 Kediri.

The Result of Partial Relationship between Frequency of Listening and Vocabulary Mastery toward Listening Ability

There are some results of the partial relationship between Frequency of Listening and Vocabulary Mastery toward Listening Ability. The first is relationship between frequency of listening and listening ability controlled by vocabulary mastery and the second is relationship between vocabulary mastery and listening ability controlled by frequency of listening.

The Result of the Partial Relationship between Frequency of Listening and Listening Ability Controlled by Vocabulary Mastery

This research purposed to find out the correlation between Frequency of Listening and Listening Ability Controlled by Vocabulary Mastery at the first grade students of MAN 4 Kediri, the researcher organized the data by using Pearson Product Moment (r) in SPSS.

Table 4.9 Correlation between Frequency of Listening and Listening Ability Controlled by Vocabulary Mastery

\section{Correlations}

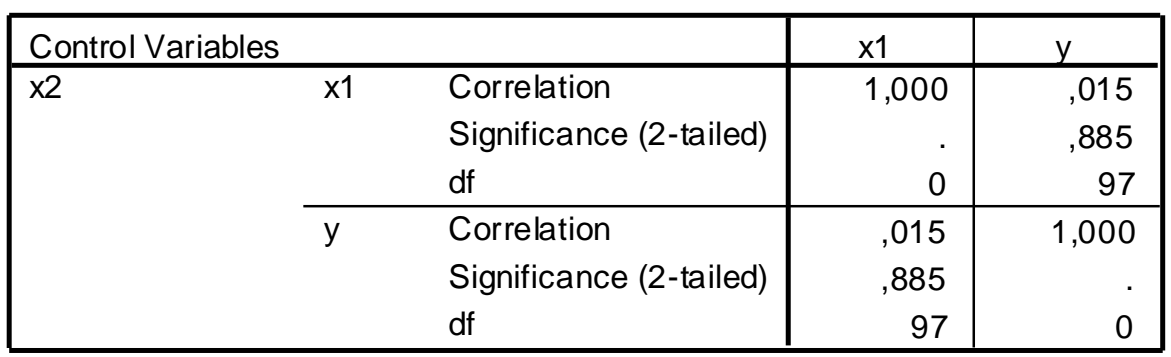


From the calculation, the relationship between frequency of listening $\left(\mathrm{X}_{1}\right)$ and listening ability $(\mathrm{Y})$ controlled by vocabulary mastery $\left(\mathrm{X}_{2}\right)$ is 0,015 or 1,5 . So, according to Sugiyono (2013), the relationship between frequency of listening $\left(\mathrm{X}_{1}\right)$ and listening ability $(\mathrm{Y})$ controlled by Vocabulary Mastery $\left(\mathrm{X}_{2}\right)$ is in very low correlation category. The significance level in 2-tailed is 0,885 . It is more than $5 \%$ significant level. It means that there is no significant partial relationship between frequency of listening $\left(\mathrm{X}_{1}\right)$ and listening ability (Y) controlled by vocabulary mastery $\left(\mathrm{X}_{2}\right)$ at the first grade students of MAN 4 Kediri.

The Result of the Partial Relationship between Vocabulary Mastery and Listening Ability Controlled by Frequency of Listening

This research purposed to find out the Correlation between Vocabulary Mastery and Listening Ability Controlled by Frequency of Listening at the first grade students of MAN 4 Kediri, the researcher organized the data by using Pearson Product Moment (r) in SPSS.

Table 4.10 Correlation between Vocabulary Mastery and Listening Ability Controlled by Frequency of Listening

Correlations

\begin{tabular}{|lll|r|r|}
\hline Control Variables & & \multicolumn{1}{|c|}{ x2 } & \multicolumn{1}{c|}{ y } \\
\hline x1 & $\mathrm{x} 2$ & Correlation & 1,000 &, 075 \\
& & Significance (2-tailed) & $\cdot$ &, 462 \\
& & 0 & 97 \\
\cline { 2 - 4 } & $\mathrm{df}$ &, 075 & 1,000 \\
& $\mathrm{y}$ & Correlation &, 462 &. \\
& Significance (2-tailed) & 97 & 0 \\
\hline
\end{tabular}

From the calculation, the relationship between Vocabulary Mastery $\left(\mathrm{X}_{2}\right)$ and Listening Ability (Y) controlled by frequency of listening $\left(\mathrm{X}_{1}\right)$ is 0,075 or 7,5 $\%$. So, according to Sugiyono (2013), the relationship between Vocabulary Mastery $\left(\mathrm{X}_{2}\right)$ and Listening Ability $(\mathrm{Y})$ controlled by Frequency of Listening $\left(\mathrm{X}_{1}\right)$ is in very low correlation category. The significance level in 2-tailed is 0,462 . It is more than $5 \%$ significant level. It means that there is no significant partial relationship between Vocabulary Mastery $\left(\mathrm{X}_{2}\right)$ and Listening Ability (Y) controlled by Frequency of Listening $\left(\mathrm{X}_{1}\right)$ was in very low correlation category.

\section{Conclusion} follows;

After analyzing the data in chapter IV, the conclusions can be drawn are as

1. The students'frequency of listening belonged to "good" category.

2. The students'vocabulary mastery belonged to "very good" category.

3. The students' listening ability on the data analysis variable Y belonged to "good" category. 
4. There is no significant simultaneous relationship between frequency of listening $\left(\mathrm{X}_{1}\right)$ and vocabulary mastery $\left(\mathrm{X}_{2}\right)$ toward listening ability $(\mathrm{Y})$ at the first grade students at MAN 4 Kediri.

5. There is no significant partial relationship between frequency of listening and listening ability controlled by vocabulary mastery at the first grade students of MAN 4 Kediri.

6. There is no significant partial relationship between vocabulary mastery and listening ability controlled by frequency of listening at the first grade students at MAN 4 Kediri.

\section{BIBLIOGRAPHY}

Brown, G. \& Yule, G. 1983. Teaching the Spoken Language. Cambridge: Cambridge University Press.

Halonen, J. \& Santrock, J.W. 1999, Psychology: Contexts and Aplications (3rded). New York: McGraw-Hill College.

Husaini, Usman. \& Purnomo, S. Akbar. 1996. Metodologi Penelitian Sosial. Jakarta: Bumi Aksara.

Kutlu, O. \& Aslanolu, Aslihan E. 2009. Factors affecting the listening skill. Turkey: Elsevier Ltd.

Nahdliyatinniswah, Sifti. 2016. Efektifitas Penggunaan Media Lagu dalam Pengajaran Listening. Diakses dari https://www.google.co.id/amp/s/siftinahdliyatinniswah.wordpress.com/201 6/04/11/contoh-penelitian/amp/. 1 Januari 2018.

Pikulsi, J John. \& Templeton, S. 2004. Teaching and Developing Vocabulary. USA: Houghton Mifflin Company.

Ramdlany, Dany M. A. 2010. Vocabulary dalam Bahasa Inggris. Diakses dari www.menulisarticleilmiahvocabularydalambahasainggris.html. 1 Januari 2018.

Setyo, Sarining. 2017. "A Correlation Study between Vocabulary Mastery, Habit of Listening to English Song and Speaking Skill of the Eleventh Grade Students of SMA N 1 Nogosari in the Academic year of 2016/2017”. Surakarta.

Sugiyono. 2013. Metode penelitian pendekatan kuantitatif, kualitatif, dan $R \& D$. bandung: alfabeta.

Ur. P. 1996. A Course in Language Teaching: Practice and Theory. New York: Cambridge University Press. 